\section{First description of pseudohypoparathyroidism with frontal lobe calcification and normal serum calcium at the initial manifestation in an otherwise healthy seven-year-old girl}

\author{
Calcificação do lobo frontal e normocalcemia como \\ primeira manifestação de pseudo-hipoparatiroidismo \\ em uma criança aparentemente saudável
}

Ana Carla Montenegro', Thais Gelenske², Érico Higino de Carvalho², Francisco Bandeira ${ }^{3}$, Everton Sougey ${ }^{1}$

\section{SUMMARY}

Pseudohypoparathyroidism (PHP) is characterized by resistance to the peripheral action of parathyroid hormone. We present a case of a seven-year-old girl who was admitted at the service of Instituto Materno Infantil de Pernambuco, IMIP, with motor episodes affecting the arms. Her calcium level was normal. Computed tomography showed calcifications in frontal lobes and basal ganglia. After six years: calcium was $5.5 \mathrm{mg} / \mathrm{dL}$; phosphorus, $8.3 \mathrm{mg} / \mathrm{dL}$ and serum parathyroid hormone was $1,318 \mathrm{pg} / \mathrm{mL}$. Pseudohypoparathyroidism diagnosis was considered. This is the first description of a case of pseudohypoparathyroidism without Albright's stigma, with cerebral calcification, and no calcium abnormalities at the initial clinical manifestation. Arq Bras Endocrinol Metab. 2011;55(5):349-52

\section{SUMÁRIO}

Pseudo-hipoparatiroidismo (PHP) é uma doença caracterizada pela resistência periférica à ação do hormônio da paratireoide. Apresentamos um caso de uma menina de 7 anos de idade que foi atendida no serviço do Instituto Materno Infantil de Pernambuco, IMIP, com crises motoras dos braços. O cálcio era normal. A tomografia computadorizada mostrou calcificações nos lobos frontais e gânglios da base. Depois de seis anos: cálcio era $5,5 \mathrm{mg} / \mathrm{dl}$, fósforo, $8,3 \mathrm{mg} / \mathrm{dl}$ e paratormônio sérico, $1.318 \mathrm{pg} / \mathrm{ml}$. Diagnóstico de pseudo-hipoparatiroidismo foi considerado. Este relato descreve o primeiro caso de pseudo-hipoparatiroidismo sem estigma Albright, com calcificação cerebral e sem alterações de cálcio na manifestação clínica inicial. Arq Bras Endocrinol Metab. 2011;55(5):349-52
Universidade Federal de Pernambuco (UFPE), Recife, PE, Brazil

2 Instituto de Medicina Integrada

Prof. Fernando Figueira

(Imip), Recife, PE, Brazil

${ }^{3}$ Universidade de Pernambuco

(UPE), Medical School,

Recife, PE, Brazil
Correspondence to: Ana Carla Montenegro anacarlapmontenegro@hotmail.com

Received on Feb/2/2011 Accepted on May/24/2011

\section{INTRODUCTION}

$\mathrm{P}$ seudohypoparathyroidism (PHP) is a rare disease characterized by resistance to the peripheral action of parathyroid hormone. PHP presents laboratory abnormalities characteristic of hypoparathyroidism (hypocalcemia and hyperphosphatemia), but with high levels of parathyroid hormone (PTH). The first description of the disease was done by Fuller Albright in 1942, who reported the cases of three patients with laboratory hypocalcemia who did not return to normal after administration of parathyroid tissue extracts (1). These individuals presented similar phenotypic characteristics: rounded face, brachydactyly, strabismus, mental retardation, ectopic calcifications, obesity and short stature $(1,2)$. This syndrome was named Albright's hereditary osteodystrophy (AHO) (1-3). Pseudohypoparathyroidism may be classified based on the renal response of cyclic adenosine 3'5'-monophosphate cyclic (cAMP) to exogenous PTH (3), AHO phenotype and the bioactivity of the protein Gs- $\alpha$. Administration of PTH causes 
a decreased response of renal cAMP in PHP types Ia and $\mathrm{Ib}$, and absence of phosphaturia in types I and II (3). Cerebral calcification of basal ganglia in states of hypoparathyroidism is not uncommon (4). In pseudohypoparathyroidism, occurrence of localized intracerebral calcification in basal ganglia is seen in around $50 \%$ of the cases (5) and, in most of these cases, clinical stigma of $\mathrm{AHO}$ is associated with such findings $(4,6)$. However, cerebral cortex calcification is rare in cases of pseudohypoparathyroidism: there are few reports in the literature $(2,7,8)$ and, to our knowledge, only three cases have been unrelated to the clinical findings typical of AHO, although all of them presented hypocalcemia at the time of diagnosis. The present study is the first description of a PHP case associated with cerebral calcification in basal ganglia and cerebral frontal cortex, with movement disorders as the sole clinical and laboratorial manifestation.

\section{CASE REPORT}

A seven-year-old girl was admitted for the first time in April 1996 at the pediatric neurology service of the Mother-Child Institute of Pernambuco (Instituto Materno Infantil de Pernambuco, IMIP), with motor episodes affecting the arms. The patient started to present this condition one month before coming to the IMIP. The episode consisted of flaccid arms and deviation of the head and eyes to the right. According to the girl's mother, the spasms were frequent and could happen up to ten times a day, without any triggering factors.

The girl had been healthy up to then, with physical and intellectual development compatible with her chronological age. Clinical examination did not show any abnormalities other than the neurological condition. There were no reports of any endocrine or neurological diseases in the family. There were no reports of physical changes that would be consistent with syndromes associated with hypoparathyroidism or pseudohypoparathyroidism.

Dietary intake of calcium was normal for the age. Serum electrolyte measurements were as follows: calcium, $8 \mathrm{mg} / \mathrm{dL}$ (reference: 8.0 to $10.6 \mathrm{mg} / \mathrm{dL}$ ); phosphorus, $6.6 \mathrm{mg} / \mathrm{dL}$ (reference: 2.3 to $5.0 \mathrm{mg} / \mathrm{dL}$ ) (Figure 1). Results for the other electrolytes, kidney function and liver function tests were normal. Computed tomography of the cranium showed calcifications in the subcortical white matter of frontal lobes, and caudate and lenticular nuclei (Figure 2). Examination of the retina was normal.

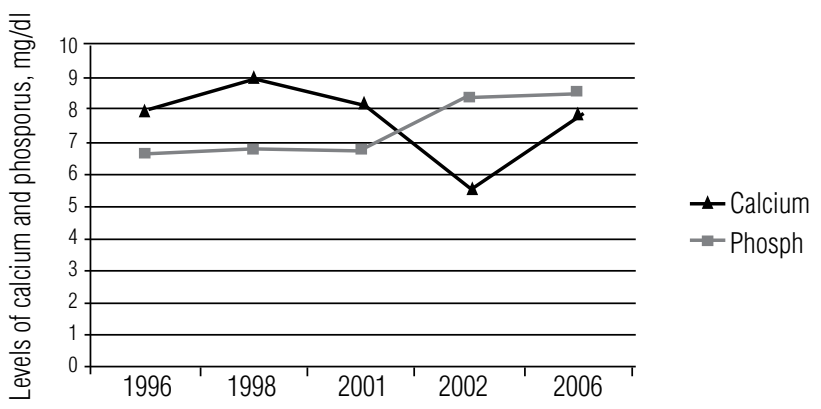

Figure 1. Calcium and phosphorus levels $(\mathrm{mg} / \mathrm{dl})$ in the patient with pseudohypoparathyroidism that were presented at the mother-child Hospital of Pernambuco (Instituto Materno Infantil de Pernambuco), Brazil.

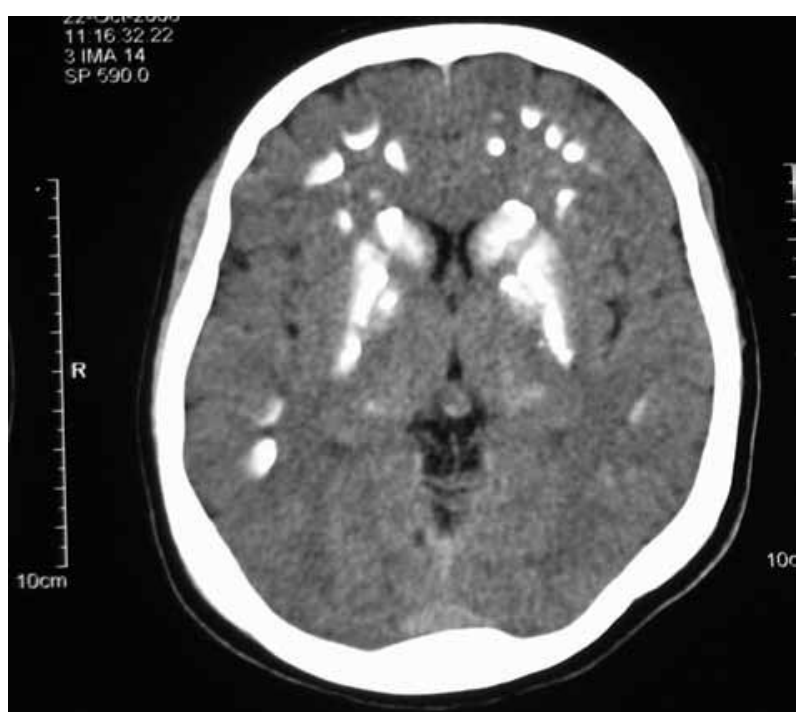

Figure 2. Computed tomography of the cranium showing calcifications in the subcortical white matter of the frontal lobes.

Diagnosis of partial epilepsy was considered, and treatment with carbamazepine was started. After initial improvement, the patient started again to present motor episodes affecting the arms. The flaccid nature was replaced by random movements of the arms, but intervals between the episodes were longer. Two years after starting to present the disease, arm movements intensified and took on characteristics resembling ballismus, with leg and trunk movements, which made it difficult for the girl to maintain an erect posture (chorea, athetosis and dystonia). These episodes lasted for around five minutes. A new computed tomography scan was done and did not show any other abnormalities.

Analysis of cerebrospinal fluid presented the following findings: two cells; proteins $48 \mathrm{mg} \%$. The electroencephalogram showed bursts of polymorphic slow waves (theta) in the right hemicranium projection. Serum electrolyte findings were: calcium, $8.9 \mathrm{mg} / \mathrm{dL}$; phos- 
phorus, $6.7 \mathrm{mg} / \mathrm{dL}$. Other medications were introduced in association with carbamazepine, in an attempt to improve paroxysmal choreoathetosis. Acetazolamide led to almost complete control over the episodes.

After three years of follow-up, the patient started again to present carpal spasms. Laboratory tests were repeated, and values were as follows: calcium, $8.2 \mathrm{mg} / \mathrm{dL}$; phosphorus, $6.7 \mathrm{mg} / \mathrm{dL}$; urinary calcium, $65 \mathrm{mg} / 24$ hours (reference: 50 to $150 \mathrm{mg} / 24$ hours); urinary phosphorus, $92.8 \mathrm{mg} / 24 \mathrm{~h}$.

Radiography of her hands and wrists to identify bone age showed values compatible with her chronological age. Patient showed spontaneous and progressive improvement, and previous medications were maintained.

During the following year, new symptoms appeared. The girl (who was now 11 years old) reported painful cramps in her hands, particularly when exposed to cold. Physical examination was positive for Chvostek's sign, Trousseau's sign and clouding of the crystalline lens. Laboratory tests presented new biochemical values: calcium, $5.5 \mathrm{mg} / \mathrm{dL}$; phosphorus, $8.3 \mathrm{mg} / \mathrm{dL}$; urinary calcium, $5 \mathrm{mg} / 24$ hours. Kidney and liver function were normal.

The pediatric endocrinology team was asked to reevaluate the patient, and serum parathyroid hormone (PTH) value was $1,318 \mathrm{pg} / \mathrm{mL}$ (reference: 10 to 65 $\mathrm{pg} / \mathrm{dL}$ ). Diagnosis was hypothesized to be pseudohypoparathyroidism, and the patient was started in calcium citrate and calcium chelate therapy. Calcitriol was administered after serum phosphorus level dropped in order to prevent precipitation of calcium phosphate in the tissues. After starting these medications, pain and motor symptoms improved. The patient made correct use of the medications for a few months and then her follow-up became irregular.

\section{Follow-up four years later}

Four years after the presumptive diagnosis of pseudohypoparathyroidism, the patient was lost to follow-up. She then came back to the pediatric neurology service with significant worsening of the intensity and frequency of her carpal and tarsal spasms. She said that she had not adhered to the medication. A new computed tomography scan of the cranium was performed, and showed that cerebral calcifications had now extended to the cerebellum. On this occasion, new laboratory test results were: calcium, $7.8 \mathrm{mg} / \mathrm{dL}$; phosphorus, 8.5 $\mathrm{mg} / \mathrm{dL}$; PTH, 1,217 pg/dL. She was started on the medications again and the symptoms receded.

\section{DISCUSSION}

Clinical expression of pseudohypoparathyroidism is variable. Most of the cases of this rare disorder that have been described are associated with somatic findings of AHO, with varying degrees of mental retardation (3). Cerebral calcifications primarily involve the basal ganglia and rarely extend to other regions of the brain. The exact pathogenesis of this phenomenon is poorly defined, but it is believed that a nonspecific process of cerebral calcification occurs, starting in the basal ganglia in the early phases of the disease, and possibly affecting other regions of the brain. When cerebral abnormalities are discovered, hypocalcemia is identified associated with the condition, which leads to investigation of parathormone deficiency.

The case reported here presented certain peculiarities. The patient's first clinical manifestation was motor, affecting her arms; initial investigation revealed intracerebral calcifications in the basal ganglia and cortical region; and no abnormalities of serum calcium were identified in laboratory tests, despite normal calcium intake for the age. The patient did not present any phenotypic characteristic that would identify AHO, either. She had normal weight and height.

To our knowledge, there are other three cases in the literature in which pseudohypoparathyroidism was associated with intracerebral calcifications, without the clinical stigma of AHO $(5,8)$. However, those patients presented hypocalcemia at the time of diagnosis, which enabled identification of pseudohypoparathyroidism, and treatment started immediately. In contrast, in the case of our patient, calcium level abnormalities occurred three years after the onset of neurological manifestations. Normocalcemia could be justified by a selective action of PTH in bone tissue, as described in some cases of PHP type Ib (1).

Independent of the etiology, calcifications of basal ganglia and other regions of the brain may be Fahr's disease. This disease is generally associated with severe hypocalcemia, symmetrical calcifications of the basal ganglia, extrapyramidal symptoms and neuropsychiatric manifestations (9). The patient did not present any neuropsychiatric manifestations and hypocalcemia appeared later than the neurological manifestations (10).

Calcification of basal ganglia has been correlated with several diseases, such as cytomegalovirus infection, toxoplasmosis and metabolic disorders, and with anoxia, therapeutic radiation, certain drugs, such as methotrexate, and carbon monoxide poisoning. There 
is an idiopathic form of calcification of the basal ganglia that occurs with advanced age (11). States of hypoparathyroidism and pseudohypoparathyroidism may also be associated with calcifications in basal ganglia. More advanced imaging techniques have demonstrated that the incidence of calcifications in this site is more frequent than it was believed. It has been estimated that between $0.3 \%$ and $1.5 \%$ of the basal ganglia calcifications are incidentally identified on computed tomography scans of the cranium (12). These calcifications most often occur symmetrically in the basal ganglia, bilaterally affecting the putamen, globus pallidus and, occasionally, the dentate nucleus. They may extend to the white matter and thalamus, thus causing focal and diffuse neurological manifestations (12). In states of pseudohypoparathyroidism, extension to the cortical matter is rarely identified (7).

In the present case, in addition to the unusual involvement of the frontal cortical region in a case of pseudohypoparathyroidism with cerebral calcification, our patient's clinical manifestations was only motor. No neuropsychiatric or cognitive disorder was identified.

In conclusion, the present report is the first description of a pseudohypoparathyroidism case in the literature without the stigma of Albright's osteodystrophy, with calcification of cerebral cortex and basal ganglia, initial clinical manifestation that was exclusively motor, and absence of serum calcium abnormalities.

Disclosure: no potential conflict of interest relevant to this article was reported.

\section{REFERENCES}

1. Maeda SS, Fortes EM, Oliveira UM, Borba VCZ, Castro L. Hypoparathyroidism and pseudohypoparathyroidism. Arq Bras Endocrinol Metabol. 2006;50:664-73.

2. Ellie E, Jullien J, Ferrer X, Riss I, Durquety MC. Extensive cerebral calcification and retinal changes in pseudohypoparathyroidism. J Neurol. 1989;236:432-4.

3. Gelfand IM, Eugster EA, Dimeglio LA. Presentation and clinical progression of pseudohypoparathyroidism with multi-hormone resistance and hereditary osteodystrophy: A case series. J Pediatr. 2000;4:397-400.

4. Illum F, Dupont E. Prevalences of CT-detected calcification in the basal ganglia in idiopathic hypoparathyroidism and pseudohypoparathyroidism. Neuroradiology. 1985;1:32-7.

5. Siejka SJ, Knezevic WV, Pullan PT. Dystonia and intracerebral calcification: pseudohypoparathyroidism presenting in an eleven-year-old-girl. Aust N Z J Med. 1988;18:607-9.

6. Cordero MM, Mories MT, Burgo RM, Fraile AL, Corrales JJ, Miralles JM. Calcificaciones readiológicas heterotópicas em dos hermanos com pseudohipoparatiroidismo. Rev Neurol. 2000;4:397-400.

7. Bloom RA, Rubinger $D$, Pogrund $H$. Frontal lobe calcification in hypoparathyroidism states. 1983;1:65-68.

8. Guberman A, Jaworski ZFC. Pseudohypoparathyroidism and epilepsy: diagnostic value of computerized cranial tomography. Epilepsia. 1979;20:541-53.

9. Cavalcanti-Mendes GA, Carvalho GT, Christo PP, Malloy-Diniz LF, Sousa AA. An unusual case of Fahr's disease. Arq Neuropsiquiatr. 2009;67(2-B):516-8.

10. Lauterbach EC, Cumming JL, Duff J, Coffey E, Kaufer D, Lovell M, et al. Neuropsychiatric correlates and treatment of lenticulostriatal diseases: a review of the literature and overview of research opportunities in Huntington's, Wilson's, and Fahr's diseases. A report of the ANPA committee on research. J Neuropsychiatry Clin Neurosci. 1998;10:249-66.

11. Cheong SK, Chan DKY. An elderly woman with calcification of the basal ganglia who presented with shuffling gait: a review with a case report. Asian J Gerontol Geriatr. 2006;1:54-6.

12. Basak RC. A case report of basal ganglia calcification. OMJ. 2009;24(3):200-22. 